international inslitute for peste resenreh. Ho was following the development of this idea with interest and hoped to discuss it with the Swedish Government when he visited Stockholm later in May. If tho Govornment was later asked to holp in any way, it would consider tho request sympathetically.

In replying to snother question on the samo day, Lord Chalfont said that, in a spcech to the United Nations Disarmament Commission on April 28, he had explained the directions in which the British Government believed that progross in disarmamont matters could and should be made. The objectives included an agreemont to prevent the future spread of nuclear weapons and an agreement on the extonsion of the partial Test Ban Treaty to includo underground tests. It was unrealistic to speak of aroas freo of nuclear weapons in isolation from tho settlement of the political problems of the areas concerned. 'The Government was firmly committed to play its full part in the defence of the Free World. It hoped to put forward British plans for arms control and disarmament, in consultation with Britain's allies, to the Eightoon-Nation Disarmament Conference which, it was hoped, would soon be re-convened at Geneva. The Conference would considor all the possibilities for nuclear-froo zones not only in Africa but in Europe and elsewhere, as well as tho various possibilities for disengagement.

\section{Communication Satellites}

IN reply to questions in the House of Cornmons on Mary 12, the Postmaster-General, Mr. A. Wedgwood Benn, said that the special agreoment on satellite communications signed in Washington in August 1964 provided for technical information about communication satellites, arising from work performed undor contracts placed by tho Committee, to be available to the signatories for use by them in work for the space sogment of the system. Certain operations, including tho Early Bird operation, for which the contract was signed earlier, were not the subject of exchange, but since the agreement came into force there was no reason to be dissatisfied with the exchange taking placo. Design studies and experiments to evaluate the relative merits of synchronous and medium-altitude satellites were now in hand by tho Intorim Communications Satellite Committeo, of which the United Kingdom was a member. It was expected that the Committeo would decide, towards the end of the year, as to the type, or types, of satellitos to be used in a global system. There was close co-operation with tho Minister of Technology on a whole range of matters bearing on the electronics and telecommunications industries, but the Post Office, through its membership of the international Committee in Washington, was rightly, with its world cable responsibilitics, the principal body responsible for international co-operation in communications.

\section{Commonwealth Bursary Scheme}

THE elevonth annual report on tho Commonwealth Bursary Scheme of the Royal Society and the Nuffield Foundation covers the yoar ended December 31,1964 , in which the Committee decided to offor 27 bursarios (London: Royal Society and Nuffiold Foundation, 1965). Details of the 22 which woro talken up are given in the report. Five were for visits from the Unitod Kingdom to Australia, 13 for visits to the United Kingdom, of which 6 were from Australia, 3 from Canada and 1 each from New Zealand, Pakistan, Rhodesia and Nyasaland, and from Trinidad. Of the 77 applications considered during the year, 60 were for visits to the United Kingdom and 10 for visits from the United Kingdom; 7 were for visits betwoen Commonwealth countries other than the United

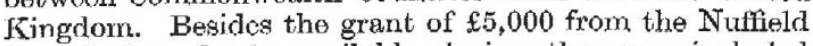
Foundation, funds available during the year included $\$ 4,000$ from the United Kingdom through a parliamentary grant to the Royal Society, $£ 2,400$ from Canada, $£ 500$ from India, £398 from Australia and $£ 100$ from Coylon.

\section{The Institution of Professional Civil Servants}

THe annual report for 1964 of the Institution of Profossional Civil Servants forms the main part of the April issue of State Service, which commonts that the report shows how much has been achieved in establishing the role of the specialist in the Government service and how much still romains to be done beforo his right to exereiso full responsibility, to take initiative and make decisions, to exercise authority to do his job without interference are fully conccded. The membership of 55,142 at December 31 , 1964, ropresents an increase of 2,478 on the year-a fall in membership in the early part of the year, partly in consequence of the reduction in staff employed by the Atomic Energy Authority and the Royal Ordnance Factories, and partly due to the increascd subseriptions, boing offset by increased recruitment later. The Institution's finances are now on a firmer footing with a sutplus of income over expenditure of $\$ 47,251$ compared with $£ 5,556$ in 1963 .

\section{Modernization in the United States}

A BOoKLET, Modernization in the United States: the Post-war Years, by Dr. K. McCann, issued by the United States Information Service (Pp. 24, 1965), deals first with tho impact of science. It is noted that whereas in 1939 American industry, universities, private foundations and the Fedoral Government spent some 500 million dollars on rescarch and its applications, Federal expenditure alone now totals 15,000 million dollars a year, and the Federal Govornmont is the foremost seeker of knowledge. The change began with the creation of tho Atomic Energy Commission in 1947 and tho subsequent devolopments in nuclear power, space research and satellites, and electronics are briefly summarized. Economic and social changes are roviewed in the following chapter, including changes in business organization, housing, the attack on povorty, and developments in education, to which are attributed primarily the social and economic fluidity of American lifo. In 1964 almost 90 per cent of Americans between 5 and 19 were enrolled in schools or universitiesan increase of 12 per cent sinco 1940 - and 9 out of every 10 children of secondary-school age were attending schools; 36 per cent of all persons of university age were enrolled in institutions of higher learning, compared with 12 per cent in 1930, and one-third of university students are now women. Brief reference is made to the improvement in the position of the Negro and to progress towards racial equality. The final chapter outlines the new tasks which the United States is now undertaking in a changing world and the consequent changes in her foreign policy.

\section{Industrial Relations}

A NEW addition to the Institute of Personnel Management's series on aspects of industrial rolations has been contributed by Allan Flanders, senior lecturer in Industrial Rolations, University of Oxford (Industrial Relations -What is Wrong with the System? An Essay on its Theory and Future. Pp. 63. London: Institute of Personnol Management, 1965. 8s. 6d. net). Mr. Flanders discusses the principles, structure and values of tho British system of industrial relations, and looks to the future. He bolieves that the necossary changes will only be brought about whon the new values implicit in the demands for national planning and workplace democracy are fully worked out and accepted as a basis for the systom's reconstruction. The primary responsibility for changing tho system rests on the Government and on management. Only management can introduce well-ordorod and co-operative systems of workplace rolations.

\section{World Health Organization Technical Reports}

THe World Health Organization continues to publish at frequent intervals its valuable serios of technical reports, which give the results of the work of expert Committeos 